\title{
Ekspresi CD3 dan CD26 pada Limfosit T sebagai Biomarker Potensial Penyakit Systemic Lupus Erythematosus
}

\author{
Yuliana Heri Suselo, Balgis, Dono Indarto \\ Departemen Fisiologi, Fakultas Kedokteran Universitas Sebelas Maret Surakarta
}

\begin{abstract}
Abstrak
Systemic lupus erythematosus (SLE) merupakan penyakit autoimun yang sering dijumpai pada wanita. Penyakit ini ditandai oleh hiperautoreaktivitas limfosit T dan B. Di dalam sistem imun, CD3 dibantu CD26 sebagai molekul kostimulator berkaitan erat dengan aktivasi dan migrasi limfosit T. Pada penyakit SLE, ekspresi CD3 dan CD26 serta aktivitas enzim CD26 belum diketahui. Tujuan penelitian ini adalah mengetahui ekspresi CD3 dan CD26 dalam darah serta kultur limfosit $\mathrm{T}$ pasien SLE. Rancangan penelitian ini bersifat eksperimen laboratorium dengan pendekatan studi retrospektif. Penelitian dilakukan di Laboratorium Biomedik, Fakultas Kedokteran Universitas Sebelas Maret Surakarta selama lima bulan (Mei-September 2012). Diagnosis SLE ditentukan menurut kriteria dari American College of Rheumatology (ACR). Darah vena diambil dari tiga pasien SLE dan dua orang sehat. Satu $\mu \mathrm{g} / \mathrm{mL}$ phytohaemmaglutinin (PHA) digunakan untuk stimulasi kultur limfosit T. Ekspresi CD3 dan CD26 ditentukan dengan flows sytometry. Substrat H-Gly-Pro pNA digunakan untuk menguji aktivitas enzim CD26. Data yang terkumpul dianalisis dengan uji t. Ekspresi CD3 dan CD26 menurun dalam darah dan kultur limfosit $\mathrm{T}$ pada pasien SLE dibanding dengan kontrol, sedangkan aktivitas enzim CD26 pada kultur limfosit T pasien SLE lebih tinggi daripada kontrol ( $0.042 \mathrm{vs} 0.030 \mathrm{U} / \mathrm{mL}$ ), tetapi perbedaan tersebut tidak bermakna secara statistik ( $p>0.05$ ). Simpulan, terdapat penurunan ekspresi CD3 dan CD26 baik dalam sirkulasi darah maupun di kultur limfosit T subtipe CD4+. CD3 dan CD26 berpotensi sebagai biomarker penting untuk SLE. Namun, riset lanjutan masih perlu dilakukan untuk menjelaskan peran keduanya dalam patogenesis penyakit SLE. [MKB. 2016;48(3):140-7]
\end{abstract}

Kata kunci: CD3, CD26, systemic lupus erythematosus (SLE)

\section{CD3 and CD26 Expression on T Lymphocytes as a Potential Biomarker of Systemic Lupus Erithematosus}

\begin{abstract}
Systemic lupus erythematosus (SLE) is an autoimmune disease that is frequently found in women and characterized by hyperautoreactivity of T and B cells. In the immune system, expressions of CD 3 and CD26 (as co-stimulatory molecule) are related to T cells activation and migration. Co-expression of CD3 and CD26 in SLE patients has not been determined. The aim of this study was to investigate the co-expression of CD3 and CD26 in blood and T cell culture of SLE patients. This was an analytical descriptive study with a retrospective approach. This study was performed at the Biomedical laboratory, Faculty of Medicine, Sebelas Maret University, for five months (May-September 2012). SLE diagnosis was determined by using the criteria from the American College of Rheumatology (ACR). Vein blood was collected from three female patients with SLE and two healthy female controls. T cells isolated from the blood were cultured and stimulated with $1 \mu \mathrm{g} / \mathrm{mL}$ phytohaemmaglutinin (PHA). Flow cytometry was used to determine the coexpression of CD3 and CD26. CD26 enzyme activities in $\mathrm{T}$ cell culture were spectrophotometrically measured using H-Gly-Pro pNA substrate. Collected data were then analyzed using Student's t test. Decreased coexpression of CD3 and CD26 was lower in blood samples and T cell cultures of SLE female patients than in control. Meanwhile, CD26 enzyme activities in SLE T cell cultures were higher than control $(0.042 \mathrm{vs} 0.030 \mathrm{U} / \mathrm{mL}$ ) but no statistical difference was found ( $\mathrm{p}>0.05)$. In conclusion, there is a decreased coexpression of CD3 and CD26 in blood circulation and T cell cultures subtype CD4+. CD3 and CD26 in SLE patients could be a prospective biomarker. Further research is required to unravel the roles of CD3 and CD26 in SLE pathogenesis. [MKB. 2016;48(3):140-7]
\end{abstract}

Key words: CD3, CD26, systemic lupus erythematosus (SLE)

Korespondensi: Yuliana Heri Suselo, dr., MSc, Departemen Fisiologi, Fakultas Kedokteran Universitas Sebelas Maret Surakarta, Jalan Ir. Sutami No.36A, Kota Surakarta, Jawa Tengah 57126, mobile 085742974531,e-mail yuliana_hsfis@yahoo.com 


\section{Pendahuluan}

Systemic lupus erythematosus (SLE) merupakan penyakit autoimun yang bersifat kronis dan banyak ditemukan pada wanita usia muda dengan manifestasi klinis yang beragam. Secara epidemiologi, angka kejadian SLE pada wanita muda sembilan kali lebih tinggi bila dibanding dengan pria dengan usia yang sama. ${ }^{1}$ Dari hasil studi meta-analisis, prevalensi SLE di negaranegara Asia bervariasi dari 30 sampai 50 kasus per 100.000 penduduk dan China menempati ranking pertama dengan 70 kasus. $^{2}$ Sampai saat ini, peneliti belum mendapatkan angka pasti prevalensi SLE di Indonesia. Data lain yang menarik adalah sejumlah wanita muda di negara barat keturunan Asia dan Afrika mempunyai kecenderungan lebih tinggi menderita SLE dibanding dengan wanita-wanita pada usia yang sama dari etnis lain. ${ }^{1}$ Namun, patogenesis SLE terkait dengan perbedaan jenis kelamin dan ras belum diketahui secara pasti. ${ }^{3}$ Beberapa faktor yang diduga sebagai penyebab SLE adalah faktor genetik, gangguan keseimbangan hormonal, disfungsi sistem imun, dan faktor lingkungan. ${ }^{4}$

Penyakit SLE INI ditandai oleh hipersekresi berbagai jenis autoantibodi terhadap molekulmolekul yang berada di membran sel, sitoplasma, dan nukleus. ${ }^{4}$ Lebih lanjut, mayoritas pasien SLE memperlihatkan reaksi positif terhadap antibodi anti double-stranded deoxyribonucleic acid (dsDNA) beberapa tahun sebelum gejala dan tanda klinis muncul.,5 Abnormalitas titer antibodi ini dijadikan sebagai salah satu kriteria diagnosis SLE. ${ }^{5}$ Berdasarkan atas studi terkini, antibodi ini banyak terlibat dalam kerusakan jaringan pada berbagai organ tubuh melalui mekanisme yang kompleks (Gambar 1). Salah satu mekanismenya adalah peningkatan proses inflamasi dengan aktivasi sistem komplemen. ${ }^{5}$

Dipetidil peptidase 4 atau CD26 merupakan protease yang terletak di membran sel-sel epitel, endotel kapiler pembuluh darah, asiner kelenjar saliva dan pankreas, serta sel-sel imun seperti limfosit T dan limfosit B. ${ }^{6}$ Khusus di limfosit T, aktivitas CD26 berkaitan erat dengan proses maturasi, migrasi, mobilitas, dan sel adhesi. ${ }^{7}$ Aktivitas DPP4 dalam serum kemungkinan berhubungan dengan aktivitas proteolitiknya yang disekresikan oleh limfosit T normal. ${ }^{7}$

Dalam beberapa studi dilaporkan bahwa aktivitas CD26 meningkatpadabeberapapenyakit autoimun. ${ }^{8,9}$ Pada kondisi fisiologis, ekspresi MHC klas II pada permukaan antigen presenting cell (APC) berfungsi untuk mempresentasikan antigen kepada limfosit $\mathrm{T}$ melalui ikatan dengan
T cell receptor (CD3). Kompleks ikatan tersebut belum mampu mengaktifkan limfosit $\mathrm{T}$ naive dan masih memerlukan molekul costimulatory lain seperti interaksi antara CD28-CD80/86 dan CD26-caveolin-1. ${ }^{9}$ Pada penyakit artritis reumatoid, sel $\mathrm{T} \mathrm{CD}^{+}$, makrofag, dan juga sel $\mathrm{B}$ menunjukkan autoaktivitas yang persisten.8,10 CD26 menstimulasi migrasi limfosit $\mathrm{T}$ dengan memodifikasi beberapa kemokin seperti CXCl12 and RANTES. ${ }^{8}$ Selain itu, ekspresi dan aktivitas CD26 meningkat signifikan di dalam cairan sinovial dan sirkulasi. Peningkatan kadar protein ini mempunyai korelasi positif terhadap derajat peradangan, ${ }^{8,10}$ sedangkan pada penyakit SLE, ekspresi dan aktivitas CD26 belum diketahui walaupun limfosit $\mathrm{T}$ dan B yang hiperautoreaktif tampak pada penyakit ini. ${ }^{11}$ Tujuan penelitian ini adalah mengetahui perbedaan ekspresi CD3 dan CD26 serta aktivitas enzim CD26 serum dan kultur limfosit $\mathrm{T}$ penderita SLE dengan orang sehat.

\section{Metode}

Penelitian ini melibatkan tiga wanita pasien SLE dari yayasan SLE 'Griya Kupu' di Surakarta, berusia 20-50 tahun. Diagnosis SLE ditetapkan dengan menggunakan kriteria ACR, minimal ada 4 dari 11 gejala dan tanda yang ada. ${ }^{12}$ Sementara itu, grup kontrol normal melibatkan dua wanita sukarela yang berbadan sehat dan berusia 20-50 tahun. Proses penelitian selanjutnya dilakukan di Laboratorium Biomedik, Fakultas Kedokteran Universitas Negeri Semarang (UNS). Protokol di dalam penelitian ini telah mendapat persetujuan dari Komite Etik Fakultas Kedokteran Universitas Sebelas Maret dan lembaran informed consent telah ditandatangani oleh setiap pasien. Bahan yang dipakai adalah Hystopaque-1077 (Sigma), media kultur komplet (MKK) terdiri atas RPMI 1640, fetal bovine serum, penicillin-streptomicin dan fungizone, PHA (Gibco), anti-CD26 MabPE (Invitrogen), dan anti-CD3 Mab FITC (BDBioscience).

Sebanyak $10 \mathrm{~mL}$ darah vena pasien SLE dan kontrol dimasukkan dalam tabung dengan antikoagulan EDTA. Sampel darah dikocok agar homogen. Sebanyak $20 \mu \mathrm{L}$ darah dimasukkan ke dalam tabung Eppendorf dan ditambah 180 $\mu \mathrm{L}$ larutan PBS pH 7,4. Sampel divorteks dan sebanyak $20 \mu \mathrm{L}$ dipindahkan ke dalam tabung Eppendorf baru. Sampel kemudian ditambah $180 \mu \mathrm{L}$ larutan BD FACS lysing solution dan diinkubasi di tempat gelap pada suhu ruang selama 10 menit. Lalu, sampel dibaca langsung 
dengan alat flows cytometer.

Isolasi limfosit mengikuti petunjuk dari Sigma. Tiga $\mathrm{mL}$ sampel darah diencerkan dengan MKK dan dimasukkan secara perlahan ke dalam tabung conical $15 \mathrm{~mL}$ yang berisi hystopaque 3 $\mathrm{mL}$. Sampel disentrifus dengan kecepatan 400 x g selama 30 menit disuhu ruang. Cincin opak kemudian diaspirasi dengan pipet pasteur dan dipindahkan ke tabung conical baru (Gambar 2). 10 mL MKK ditambahkan dan sampel disentrifus kembali dengan kecepatan $250 \mathrm{x}$ g selama 10 menit. Sel pelet diresuspensi dengan $5 \mathrm{~mL}$ MKK dan disentrifus $250 \mathrm{xg}$ selama 10 menit. Sel pelet diresuspensi dengan MKK dan siap untuk dikultur.

Sel mononuklear dipindahkan ke dalam $7 \mathrm{~mL}$ MKK yang berisi PHA $1 \mu \mathrm{g} / \mathrm{mL}$ dan kemudian diinkubasi dalam inkubator pada suhu $37^{\circ} \mathrm{C}$ dengan $5 \% \mathrm{CO}_{2}$ selama 24 jam untuk memisahkan monosit dan limfosit. Sampel sel disentrifus 500 xg selama 5 menit dan sel pelet diresuspensikan kembali dengan MKK yang berisi PHA $1 \mu \mathrm{g} / \mathrm{mL}$ dan dinkubasi pada $37^{\circ} \mathrm{C}$ dengan $5 \% \mathrm{CO}_{2}$ selama 2 hari. Sel limfosit $\mathrm{T}$ dipanen dan dipindahkan ke dalam tabung conical baru dan disentrifus seperti di atas. Sel pelet diresuspensi dengan MKK kembali dan siap digunakan untuk analisis lanjut.

$50 \mu \mathrm{L}$ sampel darah dimasukkan ke dalam tabung Eppendorf. Sebanyak $5 \mu \mathrm{L}$ anti CD3 Mab FITC atau anti CD26 Mab PE ditambahkan dan kemudian divorteks. Suspensi diinkubasi selama 15 menit di suhu ruang dan tempat gelap. 450 $\mu \mathrm{L}$ BD FACS lysing solution ditambahkan dan diinkubasi selama 15 menit. Sampel dibaca langsung dengan alat flows cytometer, sedangkan ekspresi CD3 dan CD26 dari kultur limfosit T dilakukan dengan cara sel kultur disentrifus 500 xg selama 5 menit. Sel pelet kemudian dipindahkan ke dalam tabung Eppendorf dan ditambah PBS $1 \mathrm{~mL}$. Langkah selanjutnya sama seperti pada sampel darah di atas.

Sel-sel limfosit yang telah dipanen tersebut $\left(1 \times 10^{6}\right)$ dicuci dengan PBS $\mathrm{pH} 7,4$ dua kali. Sel diresuspensikan dengan $200 \mu \mathrm{L}$ PBS pH 7,4 dan $50 \mu \mathrm{L}$ sampel ditempatkan ke dalam sumuran microplate 96. Sebanyak $50 \mu \mathrm{L} 1 \mathrm{mM}$ larutan H-Gly-Pro pNA ditambahkan ke dalam microplate reader. Setiap sampel dibuat tiga kali ulangan dan microplate diinkubasi pada suhu $37^{\circ} \mathrm{C}$ selama 60 menit. Nilai absorbansi diukur pada panjang gelombang $405 \mathrm{~nm}$. Aktivitas enzim ditentukan dengan formula Beer-Lambert $\mathrm{A}=\varepsilon \mathrm{Cl}, \mathrm{A}=$ nilai absorbansi, $\varepsilon=\mu$ molar extinction coefficient untuk pNA pada $405 \mathrm{~nm}\left(9,45 \mathrm{~L} \cdot \mu \mathrm{mol}^{-1}\right.$. $\left.\mathrm{cm}^{-1}\right), \mathrm{C}=$ konsentrasi $\left(\mu \mathrm{mol} \cdot \mathrm{L}^{-1}\right)$ dan $\mathrm{l}=$ panjang lintasan sinar $(2,94 \mathrm{~cm})$. Uji-t digunakan untuk mengetahui perbedaan antara grup SLE dan kontrol normal menggunakan program piranti lunak SPSS 11.5. Signifikansi secara statistik ditetapkan dengan nilai $\mathrm{p}<0,05$.

\section{Hasil}

Pemeriksaan hitung jenis leukosit dikerjakan untuk mengetahui perubahan jumlah sel-sel polimorfonuklear (PMN) dan mononuklear dalam sirkulasi darah pasien SLE. Secara umum, jumlah leukosit dan persentase sel-sel PMN pada pasien SLE dalam kategori normal (Tabel 1). Persentase neutrofil, eosinofil, dan monosit tampak lebih tinggi pada pasien SLE dibanding dengan kontrol walaupun peningkatannya tidak berbeda secara signifikan. Proporsi limfosit pada pasien SLE kurang lebih setengah daripada proporsi limfosit pada kontrol. Penurunan limfosit ini juga tidak berbeda bermakna bila

Tabel Gambaran Leukosit dan Aktivitas Enzim CD26 dari Kultur Limfosit T pada Pasien SLE

\begin{tabular}{lccc}
\hline & $\begin{array}{c}\text { SLE } \\
(\mathbf{n = 3})\end{array}$ & $\begin{array}{c}\text { Kontrol } \\
\text { (n=2) }\end{array}$ & $\begin{array}{c}\text { Nilai p } \\
\text { (IK; 95\%) }\end{array}$ \\
\hline Hitung leukosit & & & \\
Jumlah leukosit & 9.836 & 7.605 & 0,324 \\
Neutrofil (\%) & 67,45 & 52,05 & 0,29 \\
Eosinofil (\%) & 1,8 & 1,6 & 0,738 \\
Basofil (\%) & 0,35 & 0,4 & 0,6 \\
Monosit (\%) & 6,85 & 6,2 & 0,442 \\
Limfosit (\%) & 23,55 & 39,75 & 0,176 \\
Kultur limfosit T & & & \\
Aktivitas enzim CD26 (mU/mL) & 42 & 30 & 0,523 \\
\hline
\end{tabular}




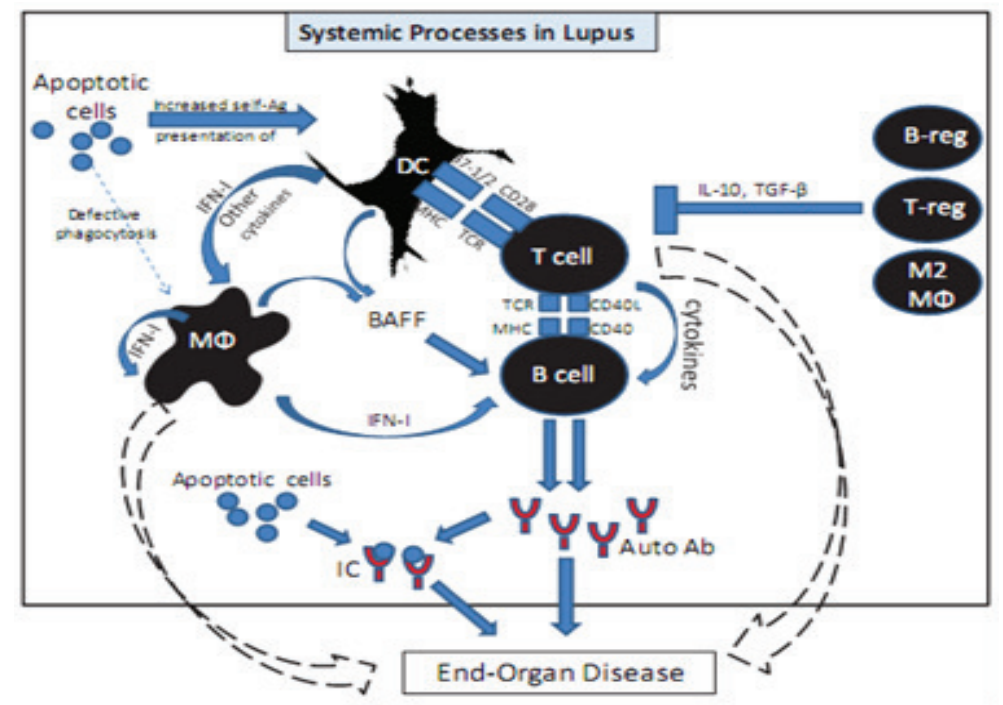

Gambar 1 Patogenesis SLE

Dikutip dari: Pathak dan Mohan ${ }^{11}$

dibanding dengan kontrol. Lebih lanjut, fraksi sel mononuklear dari sampel darah pasien SLE diisolasi dan dikultur untuk mendapatkan limfosit T. Untuk memastikan bahwa limfosit T tersebut menurun dalam media kultur, fraksi sel mononuklear dari dua sukarelawan yang berbadan sehat dijadikan sebagai kontrol positif. Gambar 3 memperlihatkan bahwa densitas selsel $\mathrm{T}$ pada SLE lebih rendah dibanding dengan densitas sel-sel T pada kontrol. Selain itu, limfosit T pada SLE mempunyai ukuran lebih besar dan intensitas pewarnaan pada nukleus lebih lemah

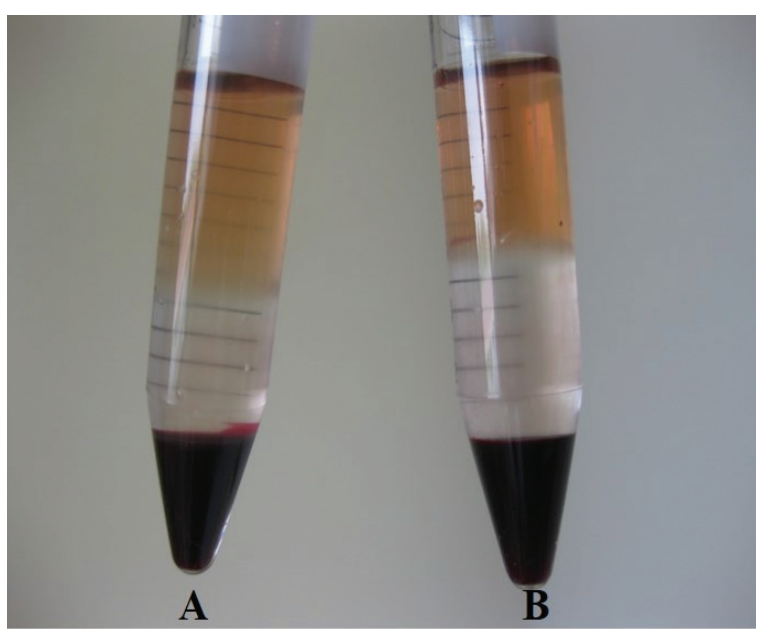

Gambar 2 Isolasi Limfosit T Darah Tepi Menggunakan Metode Hystopaque. Cincin Opak Tampak pada (A) Sampel Darah Pasien SLE dan (B) Kontrol daripada limfosit $\mathrm{T}$ pada kontrol.

Karena hasil hitung jenis leukosit dalam darah tidak dapat menggambarkan proporsi limfosit $\mathrm{T}$, dalam penelitian ini penanda membran sel CD3 dan CD26 digunakan untuk mengetahui perubahan kuantitas limfosit $\mathrm{T}$ dalam darah SLE. Ekspresi CD3 dan CD26 lebih rendah pada limfosit $\mathrm{T}$ pasien SLE daripada limfosit $\mathrm{T}$ pada kontrol (Gambar 4A-E). Dari Gambar 4E, ekspresi CD3 pada pasien SLE menurun lebih dari setengah dibanding dengan ekspresi CD3 pada kontrol (22,68\% vs $47,88 \%)$. Selanjutnya, pola yang sama juga tampak pada ekspresi CD26 tetapi ekspresi CD26 hanya menurun sekitar 18\% dalam darah pasien SLE dibanding dengan ekspresi CD26 dalam darah kontrol.

Untuk memperkuat hasil temuan penurunan ekspresi CD3 dan CD26 pada limfosit $\mathrm{T}$ dalam darah pasien SLE, ekspresi kedua penanda tersebut juga dievaluasi dalam kultur limfosit T. Dalam kultur limfosit $\mathrm{T}$ pada pasien SLE, ekspresi CD3 dan CD26 juga lebih rendah daripada ekspresi CD3 dan CD26 dalam kultur limfosit T kontrol (Gambar 5A-E). Ekspresi CD3 pada pasien SLE 13,4\% lebih rendah dibanding dengan ekspresi CD3 kontrol (21,2\%) (Gambar $5 E$ ). Pola yang sama juga terlihat pada ekspresi CD26 dalam kultur limfosit T SLE dibanding dengan kontrol $(20,57 \%$ vs $30,19 \%)$.

Sebab penanda CD26 mempunyai aktivitas enzimatis dan nonenzimatis, kultur limfosit $\mathrm{T}$ diinkubasi dengan substrat sintetik H-Gly-PropNA untuk mengetahui kemampuan aktivitas enzimatisnya untuk memotong ikatan proresidu. 

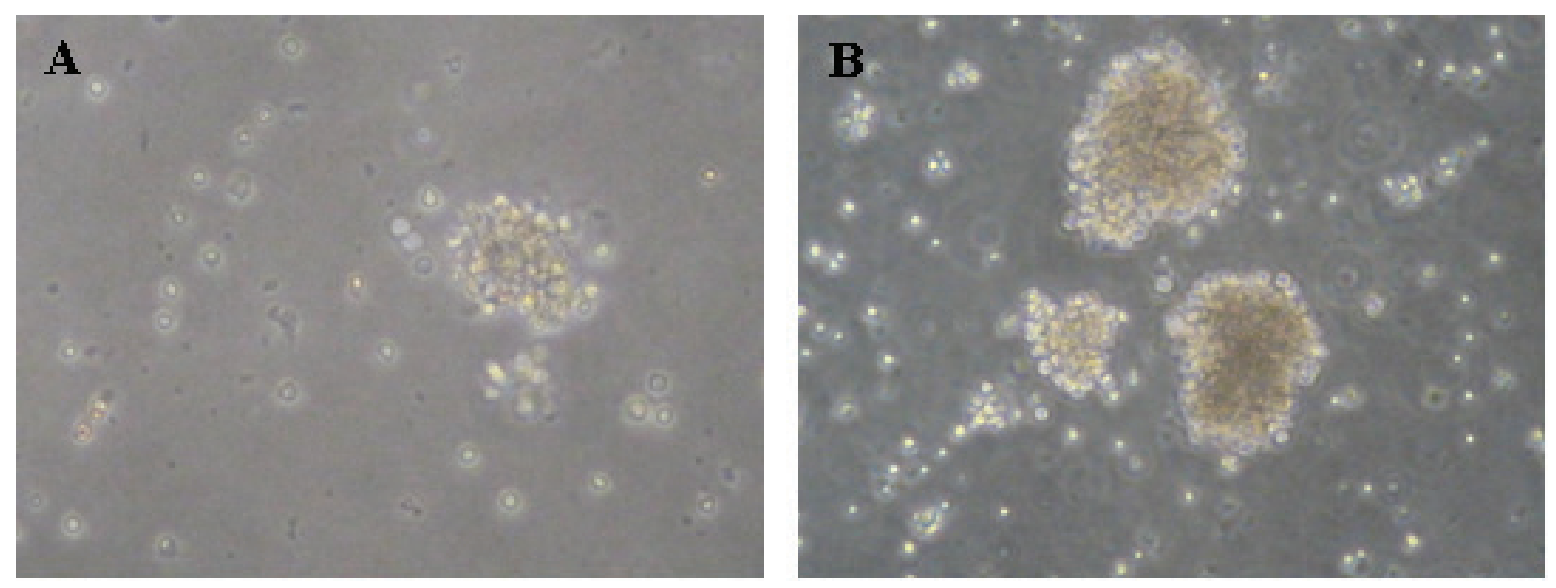

Gambar 3 Gambaran Mikroskopik Kultur Limfosit T Pasien SLE. Fraksi Sel Mononuklear Dikultur dengan PHA $1 \mu \mathrm{g} / \mathrm{mL}$ dalam MKK Selama 72 Jam. Limfosit T Subtipe CD4+ Diobservasi dengan Mikroskop Cahaya dengan 100x Perbesaran.

(A) Kultur limfosit T dari Sampel Darah Pasien SLE dan (B) Kultur Limfosit T dari Sampel Darah Kontrol

\section{A}
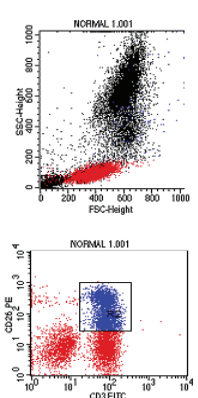

D

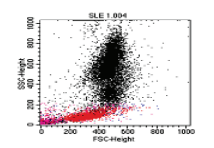

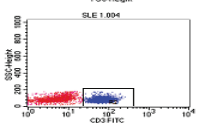

B
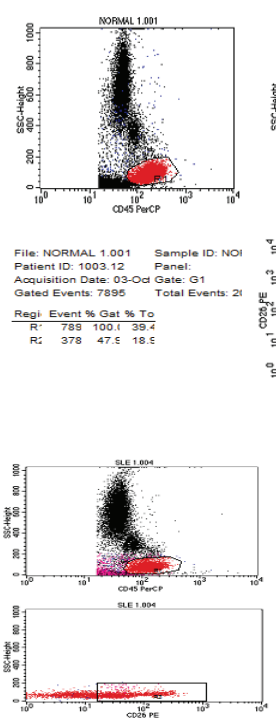

$\mathbf{E}$
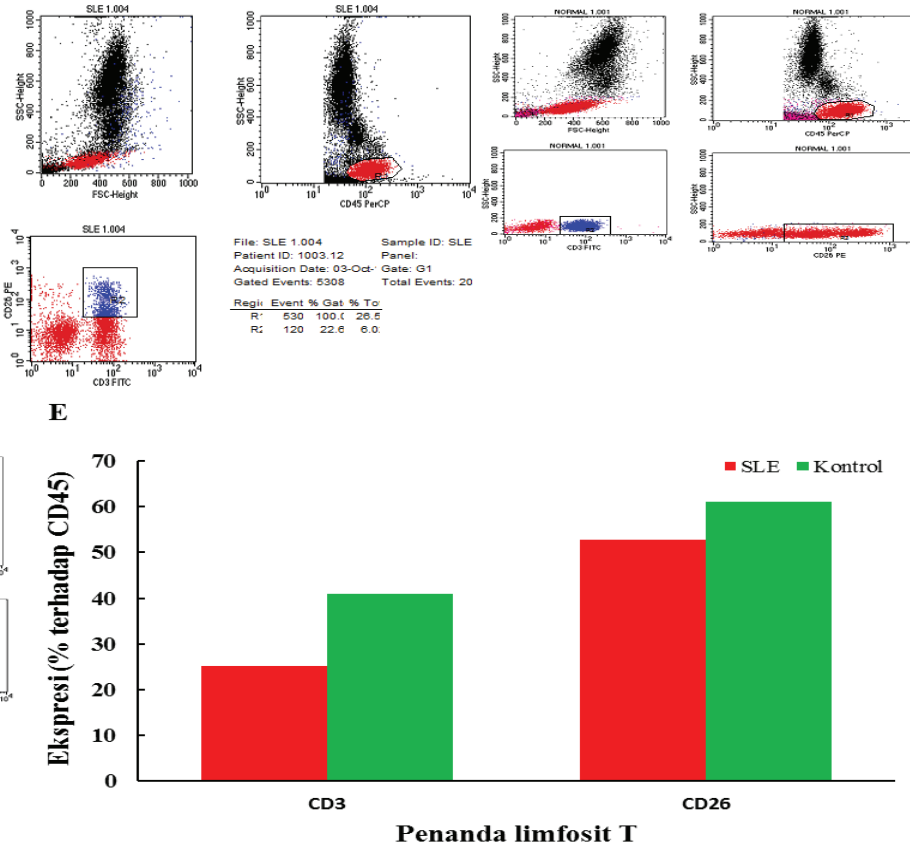

Gambar 4 Ekspresi CD3 dan CD26 dalam Sirkulasi Darah Pasien SLE

Flows sytometry analisis dilakukan dengan mereaksikan $50 \mu \mathrm{L}$ sampel darah dengan $5 \mu \mathrm{L}$ anti CD3 Mab FITC atau anti CD26 Mab PE. Suspensi sampel kemudian dicampur dengan $450 \mu \mathrm{L}$ FACS Lysing solution dan diinkubasi selama 15 menit dalam tempat gelap pada suhu kamar. (A \& B) ekspresi CD3 pada darah kontrol dan SLE secara berturut-turut. (C \& D) ekspresi CD26 pada darah kontrol dan SLE secara berturut-turut. (E) proporsi ekspresi CD3 dan CD26 terhadap ekspresi CD45 pada SLE dan kontrol. Gambar mempresentasikan 3 sampel darah SLE dan 2 sampel darah kontrol. Data disajikan dari rata-rata masing-masing sampel darah. 
$\mathbf{A}$

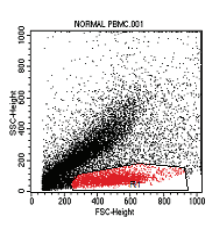

$\mathbf{E}$

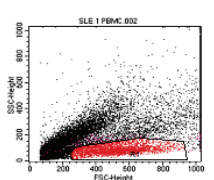

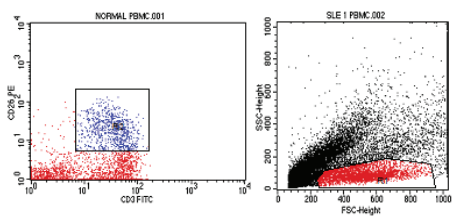
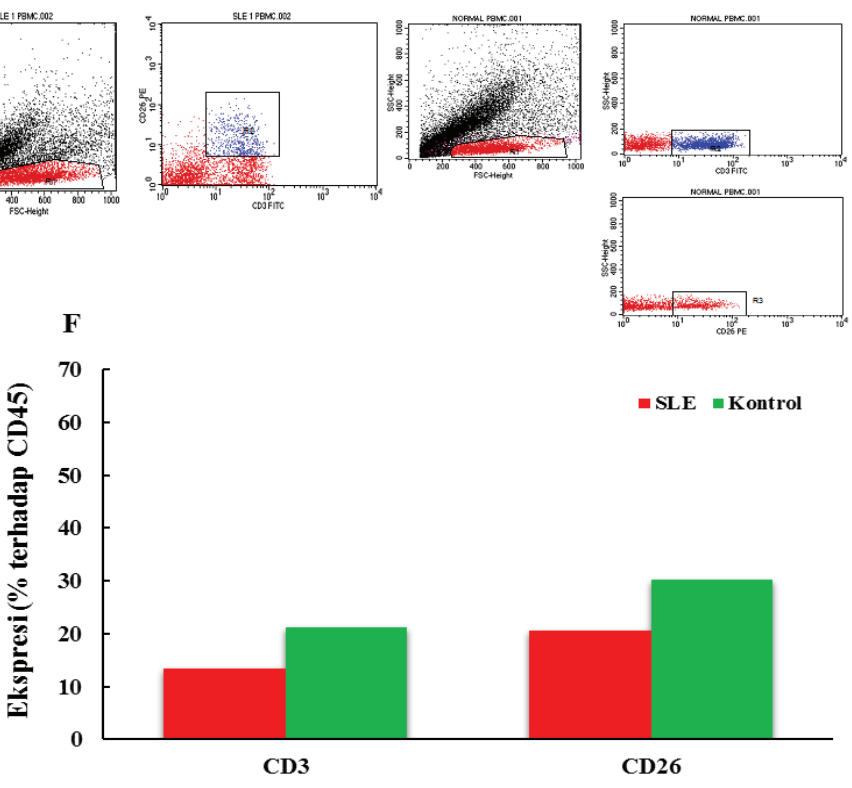

Penanda limfosit $T$

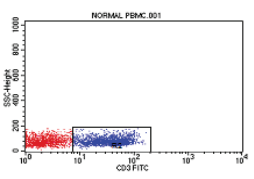

CD3

CD26
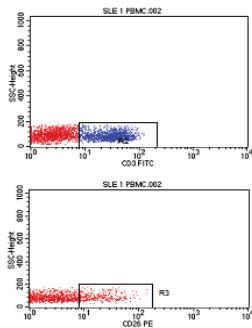

\section{Gambar 5 Ekspresi CD3 dan CD26 dalam Kultur Limfosit T Pasien SLE}

Flows sytometry analisis dilakukan meresuspensikan sel pellet ke dalam $1 \mathrm{~mL}$ PBS dan direaksikan dengan5 $\mu \mathrm{L}$ anti CD3 Mab FITC atau anti CD26 Mab PE. Suspensi sampel kemudian dicampur dengan $450 \mu \mathrm{L}$ FACS lysing solution dan diinkubasi selama 15 menit dalam tempat gelap pada suhu kamar. (A \& B) ekspresi CD3 limfosit T kontrol dan SLE secara berturut-turut. (C \& D) ekspresi CD26 limfosit T kontrol dan SLE secara berturut-turut. (E) proporsi ekspresi CD3 dan CD26 terhadap ekspresi CD45 limfosit T pada SLE dan kontrol. Gambar mempresentasikan kultur limfosit T dari 3 sampel darah SLE dan 2 sampel kontrol. Data disajikan dari rata-rata masing-masing kultur.

Tabel 1 memperlihatkan bahwa limfosit T pasien SLE mempunyai aktivitas enzim CD26 $42 \mathrm{mU} /$ $\mathrm{mL}$ sampel lebih tinggi daripada aktivitas enzim CD26 daripada limfosit T kontrol $(30 \mathrm{mU} / \mathrm{mL}$ sampel). Namun, peningkatan aktivitas enzim ini tidak berbeda bermakna secara statistik.

\section{Pembahasan}

Pada penelitian ini, sel-sel sistem imun innate meningkat dan sel-sel sistem imun adaptif menurun dalam sirkulasi darah pasien SLE. Limfositopenia pada pasien SLE ditandai oleh penurunan ekspresi CD3 dan CD26. Setelah fraksi sel mononuklear pasien SLE dikultur dan distimulasi dengan PHA, ekspresi CD3 dan CD26 juga menurun dan lebih rendah dibanding dengan dengan ekspresi CD3 dan CD26 dalam sirkulasi darah. Hal ini memperlihatkan bahwa penyakit SLE secara imunologis ditandai oleh penurunan jumlah limfosit T walaupun studi lanjutan masih diperlukan untuk mengidentifikasi apakah semua subtipe limfosit T terpengaruh dan semua penanda permukaan limfosit $\mathrm{T}$ juga mengalami abnormalitas.

Jumlah leukosit dan granulosit dalam darah pasien SLE pada penelitian ini berlawanan dengan jumlah leukosit dan granulosit pada penelitian lain yang sudah dipublikasikan sebelumnya. Peneliti telah melaporkan bahwa sebagian besar penderita SLE aktif mempunyai jumlah leukosit menurun atau leukopenia. ${ }^{13,14}$ Bahkan, leukopenia dan granulositopenia tidak jarang ditemukan pada pasien SLE di berbagai negara di belahan dunia. ${ }^{13,14}$ Perbedaan hasil pemeriksaan hematologi ini kemungkinan besar disebabkan oleh remisi penyakit SLE setelah pasien minum obat-obat imunosupresif (data tidak ditunjukkan).

Penurunan jumlah limfosit pada pasien SLE dalam studi ini sesuai dengan penelitian yang 
pernah dilakukan sebelumnya. ${ }^{13}$ Studi lain melaporkan bahwa limfositopenia pada SLE kemungkinan besar mempunyai korelasi negatif dengan peningkatan laju apoptosis limfosit $\mathrm{T}^{15}$ Selain itu, data dalam studi ini menunjukkan bahwa limfositopenia pada pasien SLE juga ditandai dengan penurunan ekspresi CD3 dan CD26 dibanding dengan dengan ekspresi CD3 dan CD26 kontrol pada orang sehat (Gambar 4 dan 5). Selain penurunan ekspresi CD3 dan CD26, beberapa abnormalitas penanda permukaan sel juga ditemukan pada limfosit pasien SLE seperti peningkatan ekspresi CD154 yang merupakan ligan CD40 pada sel $\mathrm{B}$, penurunan sekresi IL-2, dan peningkatan IFN- $\gamma .{ }^{16}$ Sebagai konsekuensinya, banyak limfosit $\mathrm{T}$ mengalami apoptosis dan juga merupakan sumber poten untuk mengaktifkan dan menginduksi antigen presenting cell imatur, meningkatkan kapasitas limfosit Tyang autoreaktif, memproduksi sitokin, dan menstimulasi limfosit B yang autoreaktif. ${ }^{15,16}$ Selanjutnya, interaksi CD154 dan CD40 akan mengaktifkan limfosit B untuk meningkatkan produksi autoantibodi yang disertai peningkatan sel-sel B dari berbagai tingkat perkembangan. ${ }^{11}$ Berdasarkan atas pengetahuan peneliti, sejauh ini belum ada pusat studi yang melaporkan penurunan ekspresi CD3 dan CD26 pada penyakit SLE baik dalam sirkulasi dan kultur limfosit T. Dengan demikian, perubahan ekspresi kedua penanda ini potensial sebagai biomarker penyakit SLE.

Dari kultur limfosit $T$ pasien SLE yang distimulasi dengan PHA, ekspresi CD3 dan CD26 menurun pada limfosit $\mathrm{T}$ subtipe $\mathrm{CD} 4^{+}$walaupun tidak menutup kemungkinan jika penurunan ekspresi CD3 dapat terjadi juga pada limfosit $\mathrm{T}$ subtipe $\mathrm{CD}^{+}$. Jadi, ekspresi kedua penanda permukaan sel tersebut memang diperlukan untuk aktivasi limfosit T naïve. ${ }^{9}$ Penyebab lain penurunan ekspresi CD3 dan CD26 adalah limfosit $\mathrm{T}$ kemungkinan tidak berproliferasi menjadi limfosit $\mathrm{T}$ subtipe $\mathrm{CD} 4$ pada saat distimulasi dengan PHA. Hal ini didasarkan pada data dari sebuah penelitian yang menyatakan bahwa ko-kultur limfosit $\mathrm{T}$ normal dengan sebuah antigen sintetik dapat mengoptimalkan proliferasi limfosit $\mathrm{T}$ subtype $\mathrm{CD} 4^{+} \cdot{ }^{17}$ Namun, penelitian lanjutan sangat diperlukan untuk membuktikan rendahnya respons limgosit T SLE terhadap stimulasi berbagai macam antigen lain seperti CD26 Mab, phorbol 12-miristat 13-asetat, atau IL-2.

Sayangnya, penurunan ekspresi CD26 pada penelitian ini tidak diikuti dengan penurunan aktivitas enzimnya (Tabel 1). Peningkatan aktivitas enzim CD26 dalam kultur limfosit SLE kemungkinan besar berasal dari anggota lain famili enzim ini seperti fibroblast activation protein serta dipeptidil peptidase 8 dan $9 .{ }^{18} \mathrm{Untuk}$ mendapatkan data aktivitas enzim CD26 yang sahih dan dapat dipercaya, metode kuantitatif baku diperlukan. Sekarang ini terdapat suatu metode standar yang dikembangkan untuk kuantifikasi aktivitas enzim CD26 dalam serum darah yang menggambarkan hanya aktivitas enzim dipeptidil peptidase $4 . .^{19,20}$

Simpulan, limfositopenia pada pasien SLE diikuiti dengan penurunan ekspresi CD3 dan CD26 baik di dalam sirkulasi darah maupun pada kultur limfosit T subtipe $\mathrm{CD}^{+}$. Perubahan ekspresi ini di masa mendatang kemungkinan dapat dikembangkan sebagai biomarker penyakit SLE yang efektif dan juga efisien meskipun riset lanjutan masih diperlukan untuk mengetahui peran kedua marker tersebut dalam patogenesis penyakit SLE.

\section{Ucapan Terima Kasih}

Peneliti mengucapkan terima kasih yang sebesar-besarnya kepada Dikti melalui Hibah Fundamental DIPA BLU UNS. Peneliti juga mengucapkan terima kasih yang dalam kepada semua pasien SLE atas dedikasinya dalam penelitian ini.

\section{Daftar Pustaka}

1. Pons-Estel GJ, Alarcón GS, Scofield L, Reinlib L, Cooper GS. Understanding the epidemiology and progression of systemic lupus erythematosus. Semin Arthritis Rheum. 2010;39(5):257-68.

2. Osio-Salido E, Manapat-Reyes H. Epidemiology of systemic lupus erythematosus in Asia. Lupus. 2010;19: 1365-73.

3. Traczewski P, Rudnicka L. Treatment of systemic lupus erythematosus with epratuzumab. Br J Clin Pharmacol. 2011; 71(2):175-82.

4. Choi J, Kim ST, Craft J. The pathogenesis of systemic lupus erythematosus - an update. Curr Opin Immunol. 2012;24(6):651-7.

5. Diamond B, Bloom O, Al Abed Y, Kowal C, Huerta PT, Volpe BT. Moving towards a cure: blocking pathogenic antibodies in systemic lupus erythematosus. J Intern Med 2011;269(1):36-44. 
6. Yu DMT, Yao T-W, Chowdhury S, Nadvi NA, Osborne B, Church WB, dkk. The dipeptidyl peptidase IV family in cancer and cell biology. FEBS J. 2010;277(5):1126-44.

7. Klemann C, Schade J, Pabst R, Leitner S, Stiller J, von Horsten S, dkk. CD26/ dipeptidyl peptidase 4-deficiency alters thymic emigration patterns and leucocyte subsets F344-rats age-dependently. Clin Exp Immunol. 2009;155(2):357-65.

8. Busso N, Wagtmann N, Herling C, ChobazPéclat V, Bischof-Delaloye A, So A, dkk. Circulating CD26 Isnegativelyassociated with inflammation in human and experimental arthritis. Am J Pathol. 2005;166(2):433-42.

9. Ohnuma $\mathrm{K}$, Inoue $\mathrm{H}$, Uchiyama M, Yamochi T, Hosono O, Dang NH, dkk. T-cell activation via CD26 and caveolin-1 in rheumatoid synovium. Mod Rheumathol 2006;16:3-13.

10. Sedo A, Duke-Cohan JS, Balaziova E, Sedova LR. Dipeptidyl peptidase IV activity and/or structure homologs: contributing factors in the pathogenesis of rheumatoid arthritis? Arthritis Res Ther. 2005;7(6):253-69.

11. Pathak S, Mohan C. Cellular and molecular pathogenesis of systemic lupus erythematosus: lessons from animal models. Arthritis Res Ther. 2011;13(5):241-9.

12. Kurien BT, Scofield RH. Autoantibody determination in the diagnosis of systemic lupus erythematosus. Scand J Immunol. 2006;64(3):227-35.

13. AlArfajA,Khalil N.Clinical andimmunological manifestations in 624 SLE patients in Saudi Arabia. Lupus. 2009;18(5):465-73.

14. Martínez-Baños D, Crispín JC, Lazo-Langner A, Sánchez-Guerrero J. Moderate and severe neutropenia in patients with systemic lupus erythematosus. Rheumatology. 2006;45(8): 994-8.

15. Dhir V, Singh AP, Aggarwal A, Naik S, Misra R. Increased T-lymphocyte apoptosis in lupus correlates with disease activity and may be responsible for reduced T-cell frequency: a cross-sectional and longitudinal study. Lupus. 2009;18(9):85-91.

16. Crispín JC, Kyttaris VC, Yuang-Taung Juang Y-T, Tsokos GC. How signaling and gene transcription aberrations dictatethe systemic lupus erythematosus $\mathrm{T}$ cell phenotype. Trends Immunol. 2008;29(3):110-5.

17. Lin Y, Gallardo HF, Ku GY, Li H, Manukian G, Rasalan TS, dkk. Optimization and validation of a robust human $\mathrm{T}$ cell culture method for monitoring phenotypic and polyfunctional antigen-specific CD4 and CD8 T-cell responses. Cytotherapy. 2009;11(7):912-22.

18. Indarto D. Validating dipeptidyl peptidase (DP) 8 and DP9 potential substrates and investigating the effects of DP8 and DP9 overexpression and silencing on adenylate kinase (AK) 2 in ovarian cancer cells. Adelaide: Flinders University; 2013.

19. Eríc-Nikolíc A, Matíc IZ, Đordevíc M, Milovanovíc Z, Markovíc I, Džodíc R, dkk. Serum DPPIV activity and CD26 expression on lymphocytes in patients with benign or malignant breast tumors. Immunobiology. 2011;216(8):942-6.

20. Jarmolowska B, Bielikowicz K, Iwan M, Sidor K, Kostyra E, Kaczmarski M. Serum activity of dipeptidyl peptidase IV (DPPIV; EC 3.4.14.5) in breastfed infants with symptoms of allergy. Peptides. 2007;28(3):678-82. 